Tahan, M., \& Kalantari, M. (2018). The Effectiveness of Preschool Education on Social Adjustment of Elementary Students. Indigenous: Jurnal Ilmiah Psikologi, 3(1), 8-14. doi:https://doi.org/10.23917/ indigenous.v3i1.5954

\title{
The Effectiveness of Preschool Education on Social Adjustment of Elementary Students
}

\author{
Mohammad Tahan ${ }^{1}$, Masume Kalantari ${ }^{2}$ \\ Islamic Azad University, Birjand, Iran. ${ }^{12}$ \\ t.mohammad2@gmail.com
}

\begin{abstract}
Considering the physical, psychological and social preparation of the child in pre-primary school for advancement in various aspects of development and the certificate of various researches, the positive effect of this course's education on the social adjustment of primary school children requires more attention to pre-school education. The elementary school is useful and necessary in terms of quantitative and qualitative and conducting appropriate studies to evaluate the effects and improve the content and conduct of the training. The purpose of this study was to investigate the effectiveness of preschool education on social adjustment of primary school students. The method of this research is post-event (causal-comparative), in which a 320-person elementary school students (160 of whom had pre-primary education and 160 without pre-school education) had adaptive behavior questionnaires. Randomized sampling was performed and the results were analyzed. . Findings of this study showed that there is no significant effect on pre-school education on social adjustment of elementary students. The results of this study confirm the view that children can not be sent to preschool centers in the hope that they will only have the effect of preschool experience on the development of their social adjustment, but also the quality of the programs of these centers, the personality and the way of communication. The teacher is the center of space and the amount of pre-school experience that matters in this area.
\end{abstract}

Keywords: Preschool Education, Social Adjustment.

\section{INTRODUCTION}

The success of the children in school depends to some extent on the events that they have experienced before entering school. Children's readiness for Word to school and their subsequent success in studying are related to different aspects of their growth. Factors such as physical, social, cognitive, knowledge and learning how to succeed in school play a role. (Birkh and Moradi ,2003) Given the advancement of science and technology in the present century, and the crystallization of the fact that the prosperity of a country has become a platform for education, the need to expand the pre-primary school is more than ever before. Therefore, it is necessary that a qualitative and quantitative program suitable for physical and mental needs for preschool children is provided, according to the characteristics of this period of development, preparation and preparation. But the prerequisite for planning and investing in this field is to carry out research on the methodology and the theoretical basis, so that, given the results obtained, some of the needs of society can be solved in this regard, .

Regarding pre-primary education, different and sometimes conflicting views are presented. On the one hand, people like (Alkind, 1987; Siegel, 1987; Cunning and Lyon, 1991; quoted by Lerrancios, 1996) argue that children should not be pushed blindly into pre-school education, and the atmosphere prevailing on many of the pre- Elementary school may not lead children as they should or maybe advancing. The reason for preparing a preschool program is that, during preprimary education, children learn experiences that may not have the positive effects of such experiences at home. But Kunning and Lyon (1991; quoted by Lerrancios, 1996) believe that 
the legend of early experiences has led us to ignore the role of adults in pre-school environments that should provide an appropriate opportunity for children. On the other hand, many scholars (eg, Dummans, 1984; Raskula, 1991; Pandie, 1991; quoted by Lerrancios, 1996) believe that pre-school experiences will have a positive effect on children's development.

(Parra, 2005; Kuntopolo 2003; Primary Child Care Research Network, 1998; B 2001; Barnet, 1995; Barashk and Moradi, 2003; Matrixi et al.,; Isaac Nia, 1994; and Darwati, 2001).. For example, many of the above studies have highlighted the useful effect of preschool education on social adjustment. Parra (2005), who measured the evolution of children aged 4 to 5 in the low-income community in Sri Lanka, found that children who were kept in preschool centers were not interested in social skills for children not in these centers. Performed significantly better. But Darthi's (2001) research suggests that preschool education does not have any effect on social adjustment.In his study in a study on the relationship between primary impact and acquisition of later education skills, using an example of a Chicago longitudinal study,

He found that there was a relationship between the parents of children attending nursery programs and cognitive abilities, family support, social adjustment, school motivation and support.

These findings indicate that environmental factors (such as family and school) are affected, and play an important role in predicting the outcomes of education. Birkh and Moradi (2003) in the study (which measured the effect of preschool education on social compatibility of elementary students) that students who have undergone preschool education have better social compatibility. Gender variables, parent's job and paternal education had no effect on social adjustment, but the variables of mother's education were effective. The emphasis on education in pre-school is due to realism, insight, effort and effort by many people who have spent their lives doing this. Given what has been said and as having children with the right education, we are looking at whether preschool education affects social adjustment of elementary students.

\section{METHOD}

The present study is a post-event (comparative study) study. In this research,

Two groups of elementary school students were selected and research tools were implemented.

A group of people who have received preschool education in kindergarten or preparation, and the second group did not have any formal education before the primary school.Statistical population and sample group The statistical population includes all students in the first, second and third year of primary school in Mashhad (iran), who study in the academic year 96. The sample group consists of 320 boys and girls, 160 of them have preprimary experience and 160 have no pre-school experience. Sampling method is a stratified random sampling. The samples were selected based on three areas of north, center and south of the city. At first, two groups were selected from among the statistical population of the subjects who had the characteristics of the two groups and randomly, two groups were selected and evaluated.

\section{Information Gathering Tool}

Datawascollected usingABICquestionnaire (Adaptive Behavior Questionnaire). The child's adaptation scale was used to measure the child's adaptation scale. This questionnaire was designed by Ahmadi in Tarbiat Modares University in 1990 based on the Adaptive Behavioral Inventory for Children. In her research, she used the level of social adjustment behavior of the child during the initial period The question of child behavioral questionnaire measures the characteristics of the child's developed social child.

The minimum and maximum score that a subject can score on this scale is zero to 94. The question of adaptive child behavior questionnaire measures the social developmental characteristics of the child. These features include: honesty, vitality, confidence, the shyness, sensitivity and irritability, the jealousy, fawning, fantasy, fear, , harassment of others, leadership and relationship with siblings and peers. The data from the questionnaire have a 
distance scale and are considered quantitatively and continuously. (Ebrahimi, 1992). Abraham (1993) confirmed the validity of the scale and expertise gained through content validity.

Ahmadi (1989) used a teacher's form of Michael Rater test to examine the validity of the scale, and a meaningful relationship was found between these two scales. Ebrahimi (1993) also obtained a reliability coefficient of $67 \%$ using the two-tiered (individual and paired) test and using the Cronbach's alpha formula. Zarishan
(2001) also obtained a 86\% reliability coefficient using Cronbach's alpha coefficient.

Procedure in this research, Ahmadi's (ABC) behavioral questionnaire (1989) was conducted on 160 primary school students attending preschool education and 160 without preschool education.

\section{FINDINGS}

The findings of the present study are presented in the following tables:

Table 1. Frequency distribution of subjects according to the trained and untrained group

\begin{tabular}{ccc}
\hline $\begin{array}{c}\text { Statistical Index } \\
\text { of Groups }\end{array}$ & Number & Percent \\
\hline Trained & 160 & 50 \\
Untrained & 160 & 50 \\
Collect all & 320 & 100 \\
\hline
\end{tabular}

Table 1 information indicates that $50 \% \quad 50 \%$ of them did not experience pre-primary of subjects have pre-primary experience, while education.

Table 2. Comparison of Mean of Girls and Boys in Social Adjustment

\begin{tabular}{ccccccc}
\hline $\begin{array}{c}\text { Significant } \\
\text { Level }\end{array}$ & $\mathbf{t}$ & $\begin{array}{c}\text { The } \\
\text { Standart } \\
\text { Deviation }\end{array}$ & Mean & Gender & Age & Variables \\
\hline \multirow{2}{*}{$0 / 314$} & $1 / 013$ & $28 / 79$ & $23 / 43$ & Girl & 7 & \\
& - & $31 / 64$ & $30 / 23$ & Boy & 7 & Social \\
$0 / 013$ & $2 / 534$ & $27 / 57$ & $19 / 95$ & Girl & 8 & Adjustment \\
& & $31 / 38$ & $33 / 98$ & Boy & 8 & \\
$0 / 827$ & $0 / 219$ & $28 / 42$ & $24 / 83$ & Girl & 9 & \\
\hline
\end{tabular}

Table 2 shows that at the age of 8 , the t-test is equivalent to 534.2 and the significance level is 0.013 . Therefore, there is no significant difference between girls and boys at the age of 7 and 8 in social adjustment, but there is a significant difference between the age of 9 years. Also, social skills are not different between girls and boys at the age of 7 and 9 , but at the age of 8 , the difference between girls and boys is significant.

10 The Effectiveness of... 
Table 3. Comparison of the mean of the two trained and untrained groups in terms of age in the variable of social adjustment

\begin{tabular}{ccccccc}
\hline Significant Level & $\mathbf{t}$ & The Standart Deviation & The Mean & Gender & Age & Variables \\
\hline \multirow{2}{*}{$0 / 510$} & $0 / 662$ & $25 / 43$ & $24 / 85$ & Trained & 7 & \\
& & $36 / 30$ & $29 / 39$ & Untrained & 7 & \\
\multirow{2}{*}{$0 / 568$} & $33 / 43$ & $28 / 86$ & Trained & 8 & Social \\
& \multirow{2}{*}{$0 / 573$} & $27 / 54$ & $25 / 59$ & Untrained & 8 & Adjustment \\
$0 / 698$ & \multirow{2}{*}{$0 / 390$} & $27 / 35$ & $24 / 49$ & Trained & 9 & \\
& & $24 / 77$ & $26 / 74$ & Untrained & 9 & \\
\hline
\end{tabular}

As shown in the Table 3, the t-test for the age of 7 was 662, for the age of 8 years, was -0.533 , and for the age of 9 , it was 0.39 , and the significance level was $0.510,0.668$, and 0.698 is. Therefore, there is no significant difference between the trained and untrained group at the age of 7, 8 and 9 in the social adjustment variable.

Table 4. Comparison of the average of trained and untrained group in gender segregation in social adjustment

\begin{tabular}{cclcccc}
\hline Variables & Gender & Educational status & Mean & The standard deviation & T test & Significant level \\
\hline \multirow{3}{*}{ Social } & Girl & Untrained & $36 / 20$ & $87 / 25$ & $701 / 0-$ & $484 / 0$ \\
adjustment & Girl & Trained & $71 / 23$ & $75 / 29$ & & \\
& Boy & Untrained & $37 / 32$ & $44 / 30$ & $758 / 0$ & $434 / 0$ \\
& Boy & Trained & $53 / 28$ & $34 / 28$ & & \\
\hline
\end{tabular}

Table 4 shows that the $T$ test for trained and untrained boys and girls in the social adjustment variable is $0.07701,-0.758$, respectively, and the significance level is 0.448 and 0.443 , respectively.

Table 5. Comparison of Means of Social Adjustment of Students Based on Maternal Employment Status

\begin{tabular}{clcccc}
\hline Variables & $\begin{array}{c}\text { Mother's } \\
\text { employment status }\end{array}$ & Mean & $\begin{array}{c}\text { The standard } \\
\text { deviation }\end{array}$ & T test & $\begin{array}{c}\text { Significant } \\
\text { level }\end{array}$ \\
\hline $\begin{array}{c}\text { Social } \\
\text { adjustment }\end{array}$ & Employed & $13 / 32$ & $42 / 30$ & & \\
\hline
\end{tabular}

As shown in the Table 5, in the social adjustment variable, $\mathrm{t}$ is 1.32 and the level of significance is $18.8 \%$. There was no significant difference in social adjustment between the two groups.

Table 6. Comparison of Means of Social Adjustment Based on Father's Job Using One-way ANOVA

\begin{tabular}{cccccc}
\hline Source changes & Sum of squares & $\begin{array}{c}\text { Degrees of } \\
\text { freedom }\end{array}$ & The mean squares & F & $\begin{array}{c}\text { Significant } \\
\text { level }\end{array}$ \\
\hline $\begin{array}{c}\text { Variance between } \\
\text { groups } \\
\begin{array}{c}\text { The variance } \\
\text { within the } \\
\text { groups }\end{array}\end{array}$ & $04 / 4230$ & 2 & $02 / 2115$ & & \\
Total & $84 / 202666$ & 217 & $95 / 933$ & $265 / 2$ & $106 / 0$ \\
\hline
\end{tabular}


The Table 6 shows that $\mathrm{F}$ for the difference between the means of social adjustment based on the father's job is 2.455 and the significance level is 0.16 . The results show that in the social adjustment variable, based on father's job, there is no significant difference between groups.

Table 7. Comparison of Means in Social Adjustment Based on Father's Education Using One-way Variance Analysis

\begin{tabular}{cccccc}
\hline Source changes & Sum of squares & $\begin{array}{c}\text { Degrees of } \\
\text { freedom }\end{array}$ & The mean squares & F & $\begin{array}{c}\text { Significant } \\
\text { level }\end{array}$ \\
\hline $\begin{array}{c}\text { Variance } \\
\text { between groups } \\
\begin{array}{c}\text { The variance } \\
\text { within the } \\
\text { groups } \\
\text { Total }\end{array}\end{array} \quad 43 / 5422$ & 2 & $21 / 2711$ & & \\
\hline
\end{tabular}

As can be seen in the Table 7, the difference significance level is 0.049 . Therefore, there is a between the means of social adjustment on the significant difference between children in social basis of father's education is 3.066 and the adjustment based on father's education.

Table 8. Tukey's test for comparing means in social adjustment based on father's education

\begin{tabular}{lccc}
\hline \multicolumn{1}{c}{ Variables } & $\begin{array}{c}\text { The mean } \\
\text { difference }\end{array}$ & $\begin{array}{c}\text { Standard } \\
\text { error }\end{array}$ & Significant level \\
\hline $\begin{array}{l}\text { Illiterate, Elementary, Cycle, Diploma } \\
\text { Illiterate, Elementary, Cycle, Super Degree }\end{array}$ & $97 / 7$ & $48 / 4$ & $179 / 0$ \\
$\begin{array}{l}\text { and higher } \\
\text { Diploma, Diploma }\end{array}$ & $29 / 3$ & $006 / 5$ & $789 / 0$ \\
\hline
\end{tabular}

As we see in the Table 8 , in the social adjustment variable, the difference between children with fathers with lower education and cycles with children with diplomas has a significant level of $0 / 179$, cycles and lower education with a higher diploma and higher, $789 / 0$, and a diploma with a diploma and Higher than 0.055 .

Table 9. Comparison of the mean of social adjustment based on mother's education using one-way

\begin{tabular}{|c|c|c|c|c|c|}
\hline \multicolumn{6}{|c|}{ ANOVA } \\
\hline $\begin{array}{l}\text { Source } \\
\text { changes }\end{array}$ & $\mathbf{F}$ & Sum of squares & $\begin{array}{l}\text { Degrees of } \\
\text { freedom }\end{array}$ & Sum of squares & Source changes \\
\hline \multirow{3}{*}{$0 / 740$} & \multirow{3}{*}{$0 / 301$} & $7 / 271$ & 2 & $4 / 543$ & $\begin{array}{l}\text { Variance between } \\
\text { groups }\end{array}$ \\
\hline & & \multirow[t]{2}{*}{$95 / 901$} & 237 & $18 / 213762$ & $\begin{array}{l}\text { The variance within } \\
\text { the groups }\end{array}$ \\
\hline & & & 239 & $58 / 214305$ & Total \\
\hline
\end{tabular}

Therefore, there is no difference between the mean of children in social adjustment based on father's education in comparison with two averages. In this way, children with an illiterate, elementary and cyclic child with children with a diploma education, as well as children with an illiterate, elementary school, children with children with a high school diploma or higher, as well as children with a high school diploma
Children with high school diploma or higher have no significant difference in social adjustment.

As the Table 9 shows, $\mathrm{F}$ for comparison of means of social adjustment of children based on maternal education is 0.301 and a significant level of 0.740 . Therefore, there is no significant difference in social adjustment based on mother's education between groups.

12 The Effectiveness of... 
This study showed that pre-primary experience in social adjustment of children did not make a significant difference. The results of Table 10 indicate that the pre-school experience did not make a significant difference in children's social adjustment, which results of this study with Parrha's researches (2005), Contupolo (2003), the primary care research network of the child (1988, 2001), Barnett (1995), Berkshak and Mardah (2003), Matrixi et al. (1364) and Isaac $\mathrm{Nia}$ (1994), and with discursive cash research (1380) is consistent.

It should, of course, be that children with pre-primary experience have better social adaptation, but the results of this research give something else. It may be possible to explain this finding to the following:

1. The type of teacher-student relationship is one of the determinants of social adjustment. Therefore, the quality of communication with the teacher may influence the growth of the child's social adjustment. Glaser (1991) believes that the quality of communication in school is one of the factors influencing the growth of children's self-esteem, and he insists that the root of most of the problems in the educational system and the teacher should be able to address the deficiencies that the child at home with Faced with school compensation. It is better to assess the type of relationship between the teacher and the child, or at least his behavioral style, in the future research.

2. Being alone in pre-school schools may not be able to lead children to social adjustment. It seems that the quality of education and the importance of children in these centers are based on what principles and foundations they learn. It is suggested that the content of educational content be analyzed in future studies to determine if one of the final objectives of the preschool education system is to increase social adjustment.

3. Although children spend some of their time in school, the quality of communication with parents and the affective affection of the family also affect the social development of children.

4. The rate of passing the pre-primary experience is one of the important variables in the social adjustment of children.

5. In most researches that have considered social adjustment, the adaptation behavior questionnaire has been completed by teachers, but in this research parents have completed their completion. Parents may be biased towards showing their children a real picture of their behavior. It is better to give this questionnaire to both parents and teachers in future research so that it can be judged better.

As stated in the introduction to the research, there are different and sometimes controversial views on the impact of preschool experience. In general, the results of this study are consistent with the idea of Alcaniand et al. (1991, cited by Lerrancius, 1996), which should not detract from children and only because the pre-school experience has a positive effect on their growth. These centers sent. However, the results of a research can not be questioned by the preschool educational system, but it is necessary to draw conclusions based on detailed research (which is of a scientific methodology and, more importantly, to come out of a definite theory).. Then, on the basis of the repetition of these studies, he developed appropriate guidelines or revised educational content. The current research has been limited including non-testing, considering educational content, not considering other aspects of development, and not considering interventional variables such as intelligence or other variables. Therefore, future research can more accurately and broadly examine the role of preschool education on the development of a child by the experimental method and by differentiating the educational content into account in many aspects of the evolution, as well as the elimination or control of the intervening variables

\section{REFERENCES}

Abrahamid, Ezmat. (1992). The Effect of Maternal Employment on Social Adolescence in Pre-school Girls in Tehran. (Master's Thesis), Tehran Teacher Training University. 
Ahmadi, Abdul Jouad (1990). Effective Factors on Adolescence of Elementary School Students in Tehran. (Master's thesis), Tarbiat Modarres University.

Isaac Nia, Hamid. (1994). The Effect of Preschool Education in Torbat Heydarieh. (Master's Thesis), Allameh Tabatabai University of Tehran.

Behrooz, Behrouz, Moradi, Shahram. (2003). The Relationship between Preschool Education and Social Adjustment of Primary School Students of Tehran in the Year 2003. (Research project), University of Welfare and Rehabilitation Sciences.

Matrisi, Abbas; Haghighat, Shahrbanoo; Yousefi, Farideh. (1364). The Effect of Preschool Education on Educational Development and Children's Intelligence in Elementary School. Quarterly Journal of Faculty of Educational Sciences (University of Tehran), Nos 3 and 4, pp. 57-55.

Sarmad, Zohreh, Bazargan, Abbas, Hejazi, Elaheh. (1379). Research Methods in Behavioral Sciences. Tehran: Aqa Publication.

Glaser, and. (1992). Schools without fail. Translation by Mehrdad Firuzbakht Tehran: Rasa.

Bilateral cash, angel. (1380). Study of the relationship between maternal employment and child social adjustment. (Master's Thesis), University of Tehran.

Barnett,W.S. (1995). Long-term effect of early childhood programs on cognitive and school out comes. Futurechild, 5, 25-50.

Canning, c. (1991). What Teachers say about reflection, Educational leadership, 48(6), 18-21.

Damon, W (1977). The social world of child. San Francisco: Jossey-Bass.

Elkind, D. (1987). Miseducation: Preschoolers at Risk. Massachusetts: Knopf Doubleday Publishing Group.

Hamp-Lyons, L. (1991). Scoring procedures for ESL contexts. In Hamp-Lyons, L. (ed.), Assessing Second Language Writing in Academic Contexts, 241-76. Norwood, NJ: Ablex.

Kontopoulou, M. (2003). Adjustment difficulties in preschool education: Greek educator"saspects. Early Child Development and Care, 173 (2-3), 259-269.

Lefrancois,G.R.(1996). The life span (5ed). Belmont: wadsworth Publishing Company.

National institute of child health and human development early child care research network (2001b). Child care and children's peer interaction at 24 and 36 months: the NICHD study of early child care. Child Development.72,1478-1500.

National institute of child health and human development early childcare research network. (1998). Early childcare and self-control, compliance and problem behavior at 24 and 36 months. Child Development .69,1145-1170.

Ou, S.R. (2005). Pathways of long-term effects of an early intervention program on educational attainment: Findings from the Chicago longitudinal study. Journa l of Applied Developmental Psychology, 26(5), 578-611.

Pandy, H. (1988). impact of the preschool education component in the icds program on the cognitive development of childern. unpublished doctoral dissertation, bharathiar university, coimbatore, india.

Perera, H. (2005). Readiness for school entry: a community survey. Journal of Royal Institute Public Health, 19,283-289.

Rescorla, L. (1991). Parent and teacher attitudes about early academic s. In: L. Rescorla, M. C. Hyson \& K. Hirsh-Pasek., eds. Academic instruction in eraly childhood: challenge or pressure?. New Jersey: Jossey-Bass.

14 | The Effectiveness of... 